ISSN 1991- 8690

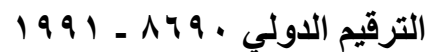

website :http:// jsci.utq.edu.iq

Email: utjsci@utq.edu.iq

\title{
Extraction and biological activity of allicin from In Vitro cultured garlic (Allium sativum L.)
}

Sabeh D. AlUtbi ${ }^{(a)}$

Dawood S. Ali ${ }^{(b)}$

Farhan L. Al-Miryani ${ }^{(a)}$

${ }^{a}$ Dept. of Biology . College of Science_ Unv. of Basrah _ Basrah. Iraq

${ }^{b}$ Dept. of Chemistry. College of Science. Unv. of Basrah. Basrah. Iraq

\section{$\underline{\text { Abstract }}$}

The shoots of garlic (Allium sativum L.) were initiated on MS (Murashige and Skoog) medium supplemented with Benzyl adenine (BA), 4mg/L which is significantly the best among other treatments $(1,2,3,5 \mathrm{mg} / \mathrm{L})$; the shoots also initiated from shoot tip in the presence of combination (NAA, 3mg/L and kinetin, $1 \mathrm{mg} / \mathrm{L}$ ); callus was also initiated from basal disc and shoot tip in the presence of combination (NAA, $5 \mathrm{mg} / \mathrm{L}$ and kinetin $0.5 \mathrm{mg} / \mathrm{L})$ and $(2,4-\mathrm{D}, 1.5 \mathrm{mg} / \mathrm{L}$ and kinetin $0.5 \mathrm{mg} / \mathrm{L}) \cdot \mathrm{R}_{\mathrm{fs}}$ values of extracted allicin from bulbs, shoots, and callus were $0.97,0.94,0.95$ respectively and the amount percentages were $1.3 \%, 1.8 \%, 2.2 \%$ respectively; identification of allicin by IR spectrum showed the similarity between the groups of extracted allicin from shoots and those of extracted allicin from bulbs (Standard); identification of allicin by UV showed one band at wave length $338 \mathrm{~nm}$ for extracted allicin from shoot and $296 \mathrm{~nm}$ for extracted allicin from bulbs (Standard).The results also showed the difference in the biological activity of extracted allicin from callus, shoots and bulbs of garlic toward Staphyllococcus aureus and Escherichia coli.

Key words: In Vitro, garlic, allicin , biological activity.

Cited from: M.Sc. Thesis

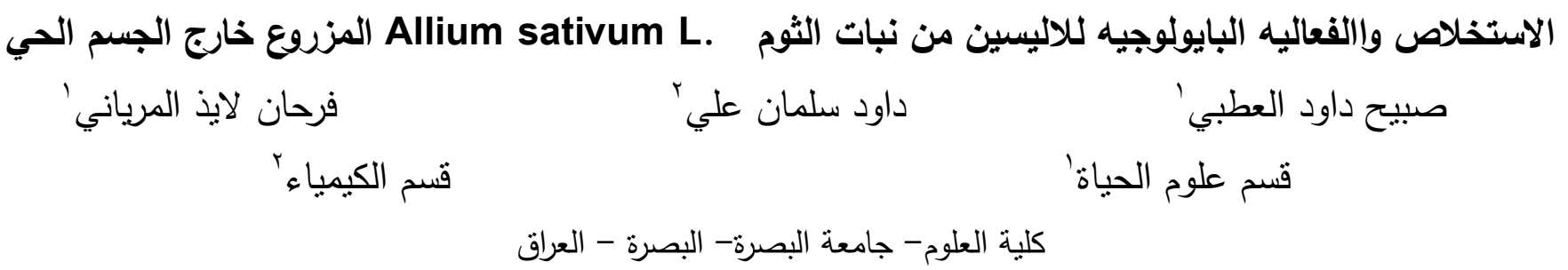

الخلاصه

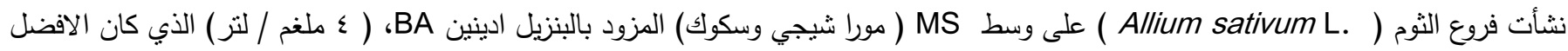

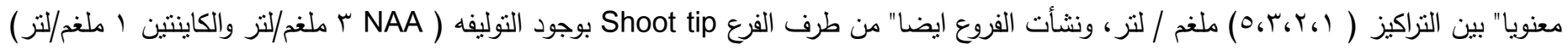

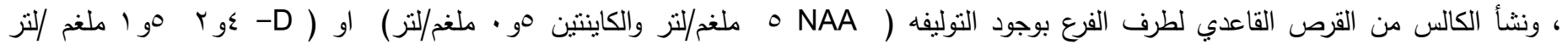

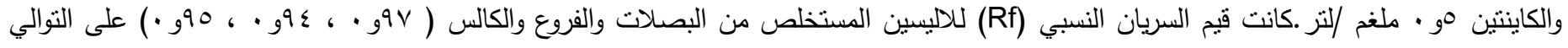

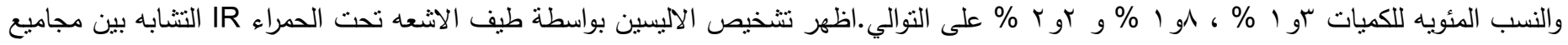
الاليسين المستخلص من الفروع وتللك المستخلصه من البصلات ( القياسي standard) اظهر تشخيص الاليسين بواسطة الاتشعه فوق البنفسيه حزمة

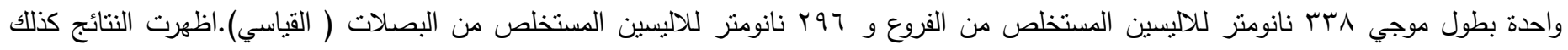

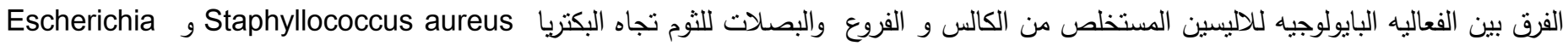




\section{Introduction}

Garlic (Allium sativum L.) which is belonging to Liliaceae is useful as medicine and food (Novak, 1990); the demand of micropropagation of garlic is for two reasons; the first is sexual sterility of the plant and the second is the capability of the production of secondary metabolites; Chen and Huang (1991) used the shoot tip in tissue culture of garlic and they emphasized on the activity of induction of adventitious shoots from basal disc tissues on (MS) medium supplemented with NAA (naphthalene acetic acid), 0.6mg/L, BA (Benzyl adenine), 2mg/L. Ayabe and Sumi (2001) proved that the basal disc of garlic has atotipotency of micropropagation; Masuda et al. (1994) reported that the rings of basal disc of bulbs produce a multiplied shoots on MS medium containing NAA and BA; however, BA was the most effective stimulator for shoot formation and increased the percentage of growth (Choi et al., 1993; Kudou et al., 1995); Changhua et al. (1995) found that MS medium supplemented with BA, $1-2 \mathrm{mg} / \mathrm{L}$, NAA, $0.1 \mathrm{mg} / \mathrm{L}$ causes an increase in the regeneration of garlic buds. Nagasawa and Finer (1988) obtained callus from leaf primordial and meristematic tissues of garlic by using 2,4-5T (2,4-5 trichlorophenoxy acetic acid), dichamba and picloram; Khan et al. (2004) stated that the high percentage of embryagenic callus initiation was at combination 2,4-D, $1.5 \mathrm{mg} / \mathrm{L}$ and kinetin $5 \mathrm{mg} / \mathrm{L}$., the callus itself produces a high number of shoots on MS medium supplemented with BA (10mg/L); Cavalito et al. (1944) isolated allicin (volatile oil ) and studied its chemical and physical properties; inactive allicin was converted to active allicin in garlic extract at $37^{\circ} \mathrm{c}$ for an hour (Tynecka and Gos, 1973); Jerzy and Lipo (1990) found that fresh garlic extract is more active than commercial type during to the high content of allicin; garlic is rich with organic sulfur compounds of medical uses in curing some diseases such as bronchitis (Chakravarty, 1976 ; Block, 1985); Saleem (1978) found that the yeast Sacharomyces cereviceae more sensitive than bacteria toward the garlic extract; garlic has biological activity as antibiotic to bacteria Vibrio spp. , Streptococcus fecalis, Proteus vulgaris, Salmonella typhi, Pseudomonas aerreginosa and Bacillus cereus (Chen et al. 1985; Takagi, 1990; Koch, 1993; Pai and Platt, 1995); Barros and Maia (1995) stated a close inverse relationship between the diameters of fungal colonies and the concentration of garlic water extract; Lowson (1998) stated that the allicin derivatives DATS (Diallyl trisulfide) and Ajoene have antimicrobial activity in human body less than allicin itself; our current study has been aimed to recognize if there is an effect of tissue culture treatment on the induction of allicin production and its biological activity.

\section{Materials and Methods}

\section{Tissue culture:}

MS medium was prepared from MS basal salts (Murashige and Skoog, 1962) supplemented with following materials (mg/L):Sucrose (30000), NaH2PO4 (170), meso-lnositol (100) thiamine-HCl (0.5), Agar (8000), activated charcoal (3000) whereas auxins and cytokinins were added in the following combinations and purposes: BA at levels $(0,1,2,3,4,5) \mathrm{mg} / \mathrm{L}$ used for culturing shoot tip with basal disc; NAA (3mg/L) and kinetin $(1 \mathrm{mg} / \mathrm{L})$ used for culturing shoot tip; BA $(1 \mathrm{mg} / \mathrm{L})$ used for culturing shoot tip with basal disc; NAA $(5 \mathrm{mg} / \mathrm{L})$ and kinetin $(0.5 \mathrm{mg} / \mathrm{L})$ used for culturing basal disc; $2,4-\mathrm{D}(1.5 \mathrm{mg} / \mathrm{L})$ and kinetin $(0.5 \mathrm{mg} / \mathrm{L})$ used for culturing basal disc; $\mathrm{pH}$ was adjusted at (5.8) than agar and activated charcoal were added, the medium was heated, cooled and dispensed at $25 \mathrm{ml}$ liquotes in tubes $(15 \times 180 \mathrm{~mm})$ or in $50 \mathrm{ml}$ liquotes in flasks, the containers were autoclaved at $121^{\circ} \mathrm{c}$ for $15 \mathrm{~min}$.

\section{Extraction of allicin:}

Allicin was extracted from bulbs and In vitro propagated shoots of garlic; Procedure of Cavalito et al. (1944) was applied with modification that normal hexanol was substituted by normal butanol in separation and filteration (Al-Wafi, 1998); allicin was identified by TLC (Thin Layer Chromatography Technique) In which ethanol (95\%) was used as solvent .according to (Khanna and Rathore, 1977); Relative flow coeffecients (Rfs) were determined, IR (infra red) spectrum of isolated allicin from alcoholic extract was measured at frequency $500-4000 \mathrm{~cm}-1$ according to (Shriner, 1980); UV (altra violet) spectrum of isolated allicin from alcoholic extract was measured at frequency $200-800 \mathrm{~nm}$ by spectrophotometer according to Harborne, (1984).

\section{Biological activity:}

Staphyllococcus aureus ATCC25923 and Escherichia coli ATCC25922 were prepared on slant nutrient broth medium and incubated at $37^{\circ} \mathrm{c}$ for $24 \mathrm{hrs}$; dilutions were made up to 0.1 (optimum density) by spectrophotometer; Muller-Hinton agar medium was prepared in petri dishes according to Kirby and Bauer test (Bauer et al. 1966); after autoclaving the medium was incubated at $37^{\circ} \mathrm{c}$ for $24 \mathrm{hrs}$. for the following tests: $400 \mathrm{mg}$ of allicin were dissolved in $10 \mathrm{ml}$ of ether in test tube, small discs of filter papers were imbibed with 
allicin for $3 \mathrm{hrs}$ in petri dishes up to saturation level $40 \mathrm{mg}$ by evaporation of ether from the petri dishes ; $0.1 \mathrm{ml}$ of nutrient broth which contains activated bacteria was cultured homogenously on Muller-Hinton medium for 15-30min., then inoculated with discs of allicin and control in a close contact between the discs and the surface of culture media, the cultured petri dishes were incubated at $37^{\circ} \mathrm{c}$ for $24 \mathrm{hrs}$; diameters of inhibition zones were measured. SPSS program is used for statistical analysis including L.S.D. test at $\mathrm{P}<0.01$, 0.05 and complete randomized design were applied.

\section{Results and Discussion}

\section{Tissue culture:}

The shoots were initiated from shoot tip with basal disc in the presence of BA $(4 \mathrm{mg} / \mathrm{L})$ or $(1 \mathrm{mg} / \mathrm{L})$ (fig.1), thus the treatment $(4 \mathrm{mg} / \mathrm{L})$ showed a significant differences among other treatments $(1,2,3,5 \mathrm{mg} / \mathrm{L})$ (Table 1) and the shoots were also initiated from shoot tip in the presence of combination (NAA, $3 \mathrm{mg} / \mathrm{L}$ and kinetin, 1mg/L) (fig. 2).

Table (1): The effect of BA on the shoots initiation

\begin{tabular}{|l|c|c|c|c|c|c|}
\hline$(\mathrm{mg} / \mathrm{L})$ & 0 & 1 & 2 & 3 & 4 & 5 \\
\hline Fresh weight $(\mathrm{mg})$ & 550 & 562 & 524 & 776 & 1064 & 784 \\
& $*_{\mathrm{b}}$ & $*_{\mathrm{b}}$ & $\mathrm{b}$ & $\mathrm{b}$ & $\mathrm{a}$ & $\mathrm{b}$ \\
\hline \hline
\end{tabular}

*different letters indicate significant differences at $\mathrm{P} \leq 0.01$.

These results corroborated with the finding of Kodou et al. (1995) and Choi et al. (1993) who reported that BA was most effective stimulator for shoot formation and increasing the percentage of shoot regeneration, however, Hassan et al. (2007) used MS medium containing BA $(0.01 \mathrm{mg} / \mathrm{L})$ in micropropagation of garlic.Shoot induction in the presence of combination (NAA, 3mg/L and kinetin, $1 \mathrm{mg} / \mathrm{L}$ ) was corroborated with the finding of Roksana et al. (2002) who observed the shoot induction on semisolid medium in the treatment NAA, $2 \mathrm{mg} / \mathrm{L}$ and Kinetin, $2 \mathrm{mg} / \mathrm{L}$, however Roksana et al. (2002) reported that the combination of cytokinin and auxin is better for early establishment of shoot apex than cytakinin alone; the callus was initiated from basal disc and from shoot tip in the presence of combination (NAA, $5 \mathrm{mg} / \mathrm{L}$ and kinetin $0.5 \mathrm{mg} / \mathrm{L}$ ) (fig. $3,4)$ or from shoot tip at combination $(2,4-\mathrm{D}, 1.5 \mathrm{mg} / \mathrm{L}$ and kinetin $0.5 \mathrm{mg} / \mathrm{L}$ ) (fig. 5); these results corroborated with the finding Khan et al. (2004) who obtained the higher percentage of callus formation at combination $2,4-\mathrm{D},(1.5 \mathrm{mg} / \mathrm{L})$ and kinetin $(5 \mathrm{mg} / \mathrm{L})$; Robledo et al. (2000) who reported that the good callus induction was observed by using root tip in the presence of combination 2,4-D and kinetin; Generally. the importance of basal disc in the initiation of both shoots and callus may be due to the meristematic activity, however, Masuda et al. (1994) reported the importance of basal disc in the micropagation of garlic.

\section{Extraction:}

Rfs values of extracted allicin were: $0.97,0.94,0.95$ from bulbs, shoots and callus respectively (fig. 6); these results were in approach with the finding of Alwafi (2001) who reported that the Rf value of extracted allicin was 0.96.Table (2) showed the amounts and the percentages of extracted allicin from three of garlic plant parts:

Table 2: The amounts and percentages of extracted allicin from bulbs, shoots and callus of garlic

\begin{tabular}{|l|c|c|}
\hline Percentage & Amount (mg) & Plant part \\
\hline $1.3 \%$ & 325 & Bulbs \\
\hline $1.8 \%$ & 450 & Shoots \\
\hline $2.2 \%$ & 560 & Callus \\
\hline
\end{tabular}

These results indicate the importance of tissue culture in increasing the amount of extracted allicin; the important groups of IR spectrum of extracted allicin were indicated in table (3) and fig. (7) whereas those of extracted allicin from bulbs were showed in fig. (8).

Table (3): Absorption bands and related active groups in IR spectrum of allicin

\begin{tabular}{|l|l|l|}
\hline \hline Band frequency $\mathrm{cm}^{-1}$ & Band & Active group \\
\hline $3062-3026$ & $=\mathrm{CH}_{2}$ & $=\mathrm{CH}_{2}$ \\
\hline 2921 & $-\mathrm{CH}_{2}-$ & $-\mathrm{CH}$ in aliphatic compound \\
\hline 2850 & $-\mathrm{CH}_{2}-$ & $-\mathrm{CH}_{2}$ in aliphatic compound. \\
\hline 1598 & $-\mathrm{C}=\mathrm{C}-$ & Doublet due to rotational isomerism \\
\hline 1026 & $\mathrm{~S}=\mathrm{O}$ & $\mathrm{S}=\mathrm{O}$ in alkyl sulfoxides \\
\hline 696 & $\mathrm{C}-\mathrm{S}$ & $\mathrm{C}-\mathrm{S}$ in sulfonyl compound \\
\hline
\end{tabular}

As a comparison between important groups of extracted allicin from shoots and these from bulbs (standard) were observed nearly similar in their values which were 696, 1026, 1598, 2062, 3026, 2921, $2850 \mathrm{~cm}-1$ indicating the presence of the groups, $(\mathrm{C}-\mathrm{S})$, $(\mathrm{S}=\mathrm{O}), \mathrm{C}=\mathrm{C},=\mathrm{CH} 2,=\mathrm{CH} 2,-\mathrm{CH} 2-,-\mathrm{CH} 2$ respectively for allicin from shoots of garlic whereas: 695, 1050, $1550,3020,3055,3000,2940,2890,2820 \mathrm{~cm}-1$ indicating the presence the groups, $(\mathrm{C}-\mathrm{S}),(\mathrm{S}=\mathrm{O}), \mathrm{C}=\mathrm{C}$, $=\mathrm{CH} 2,=\mathrm{CH} 2$, $-\mathrm{CH} 2-,-\mathrm{CH} 2-,-\mathrm{CH} 2,-\mathrm{CH} 2$ respectively for allicin from bulbs of garlic (fig. 8), however. Brace (2002) reported that etheral extraction of garlic bulbs 
contain allicin related compounds such as cystein and cystein sulfoxides gamma; the results of UV spectrum showed one band at wave length $338 \mathrm{~nm}$ of isolated extracted allicin from shoots (fig.9) and $296 \mathrm{~nm}$ of standard allicin from bulbs (fig.10), those results due to the transition $n \rightarrow \pi$ as indicator of the presence of atoms with free lone pair of electrons such as $\mathrm{N}^{\prime}, \mathrm{S}^{\prime}, \mathrm{O}^{\prime \prime}$ in the chemical structure of organic compounds, however. Staba (2001) pointed out that steam distillation of organic produces allyl sulfides compounds such as DAS diallyl sulfides, DADS (Diallyl disulfides) and DATS (Diallyl trisulfides); Lowson (1998) stated that fresh garlic contains Gamma-glutamyl S-allyl cystein) and alliin; the results also showed in (fig. 11) and (fig. 12) that the biological activity of extracted allicin from callus and shoots is higher than that of extracted allicin from bulbs, this may be due to an increase in the temperature and storage period length in the case of extracted allicin from bulbs cause the chemical and physical changes in the different compounds of garlic, especially, allicin, allinase.Borukh et al. (1975) found that antibacterial activity of garlic diminished during storage at $16^{\circ} \mathrm{c}$ more than at $0^{\circ} \mathrm{c}$. The variance in biological activity of allicin between callus the induction of callus and bulbs may be also due to the induction of callus by hormone treatments, however, Zenk (1978) reported that there are many compounds of economic importance such as antibiotics could be produced from callus better than from organs cultures.
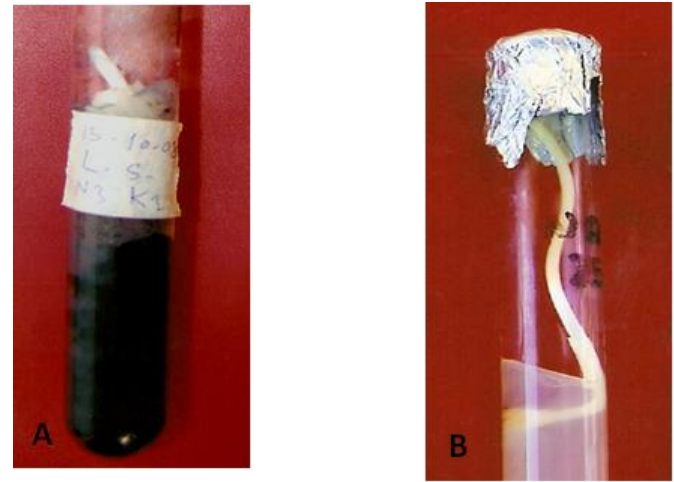

Fig. 1: Initiation of shoots on MS medium A-from shoot tip using (NAA, 3mg/L and kinetin $1 \mathrm{mg} / \mathrm{L})$

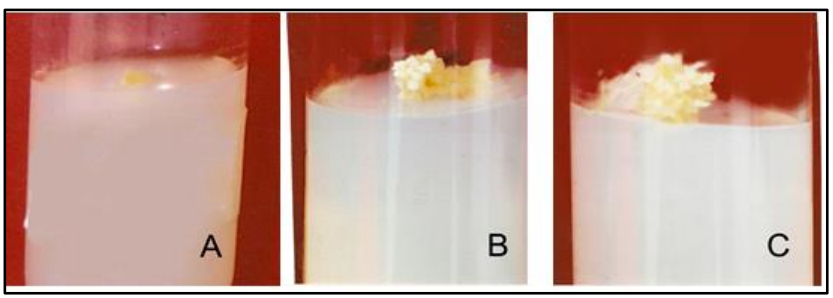

Plate 1: Initiation of callus from basal disc using

(NAA, $5 \mathrm{mg} / \mathrm{L}$ and Kinetin $0.5 \mathrm{mg} / \mathrm{L}$ ). A- after 2 weeks B- after 2 months C-after 3 months

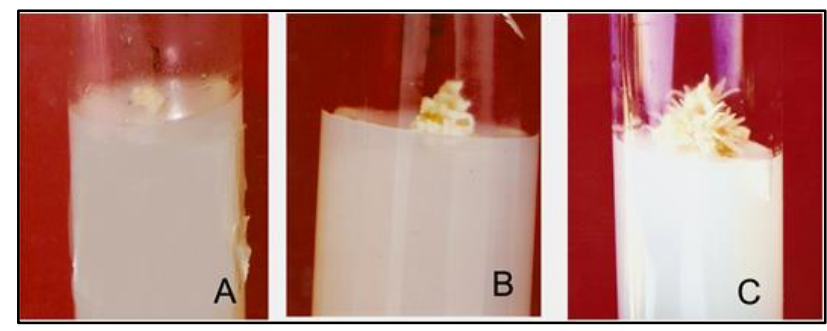

Plate 2: Initiation of callus from shoot tip using (NAA, 5mg/L and Kinetin 0.5mg/L). A- after 2 weeks

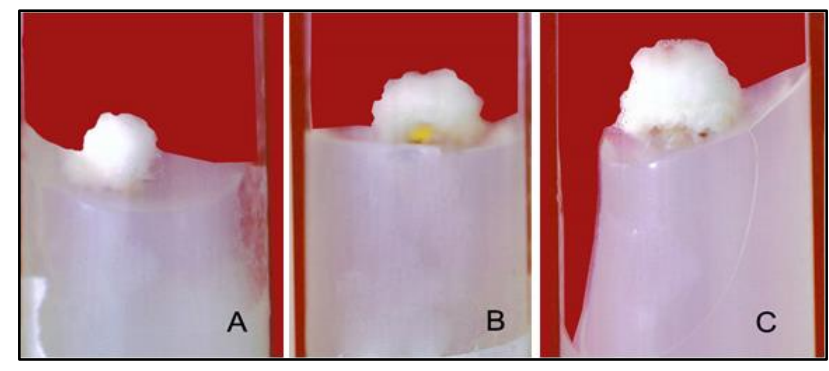

Plate 3: Initiation of callus from basal disc using (2,4D, $1.5 \mathrm{mg} / \mathrm{L}$ and Kinetin $0.5 \mathrm{mg} / \mathrm{L}$ ). A- after 10 days B- after 15 days C-after 30 days

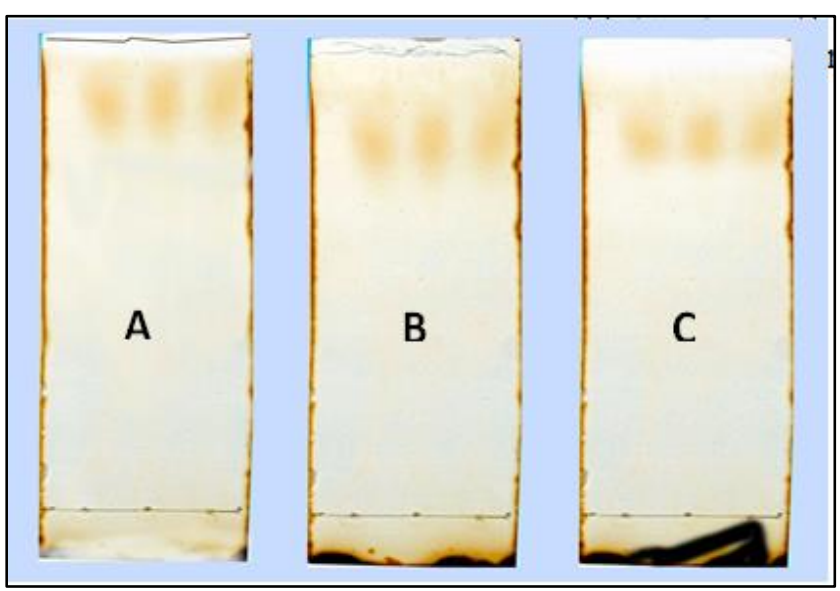

Plate 4: TLC of isolated allicin from: A- Bulbs BShoots C-Callus 


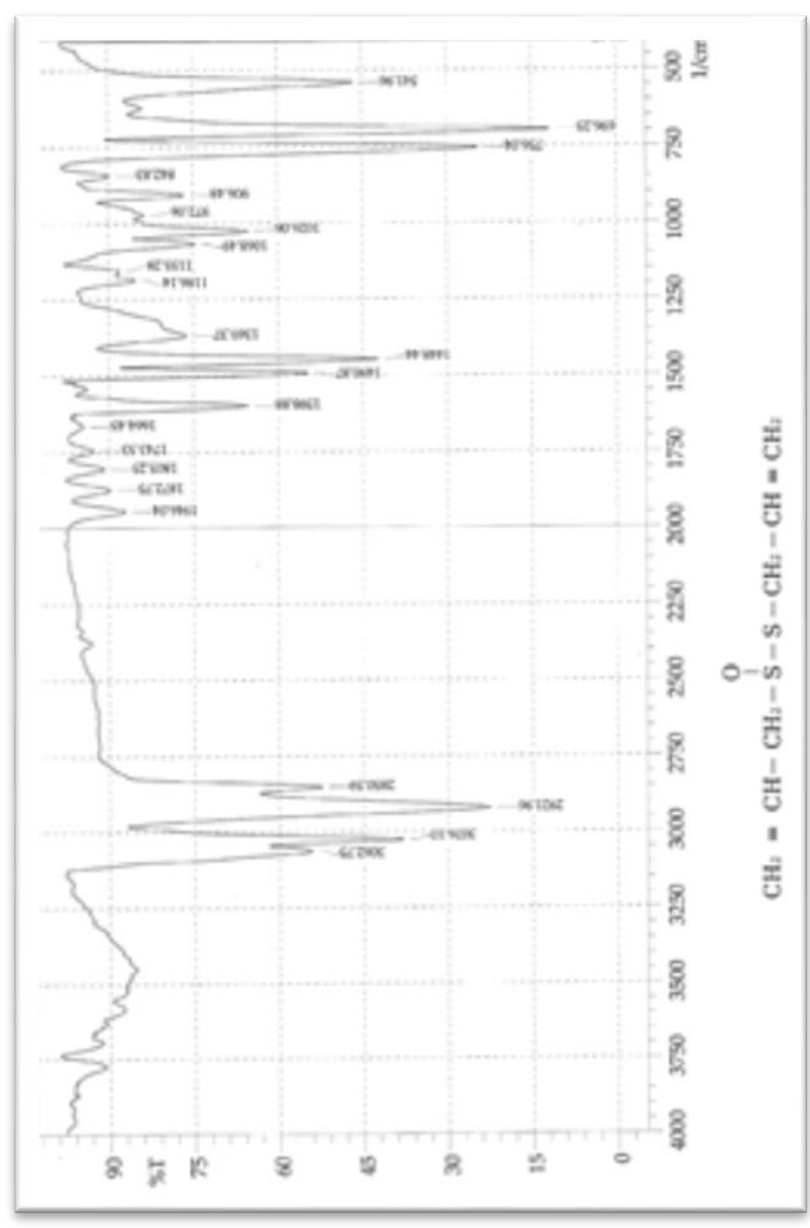

Fig. 7: I.R spectrum of isolated allicin from shoots of garlic

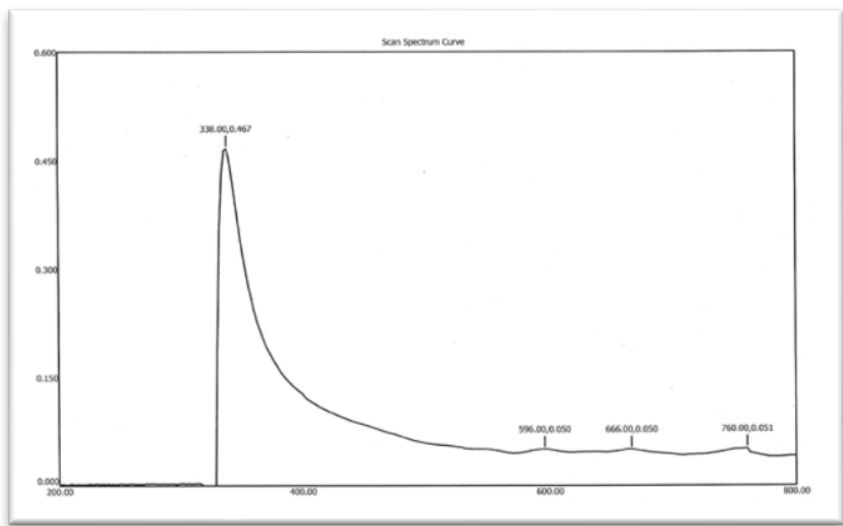

Fig. 9: U.V spectrum of isolated allicin from shoots of garlic

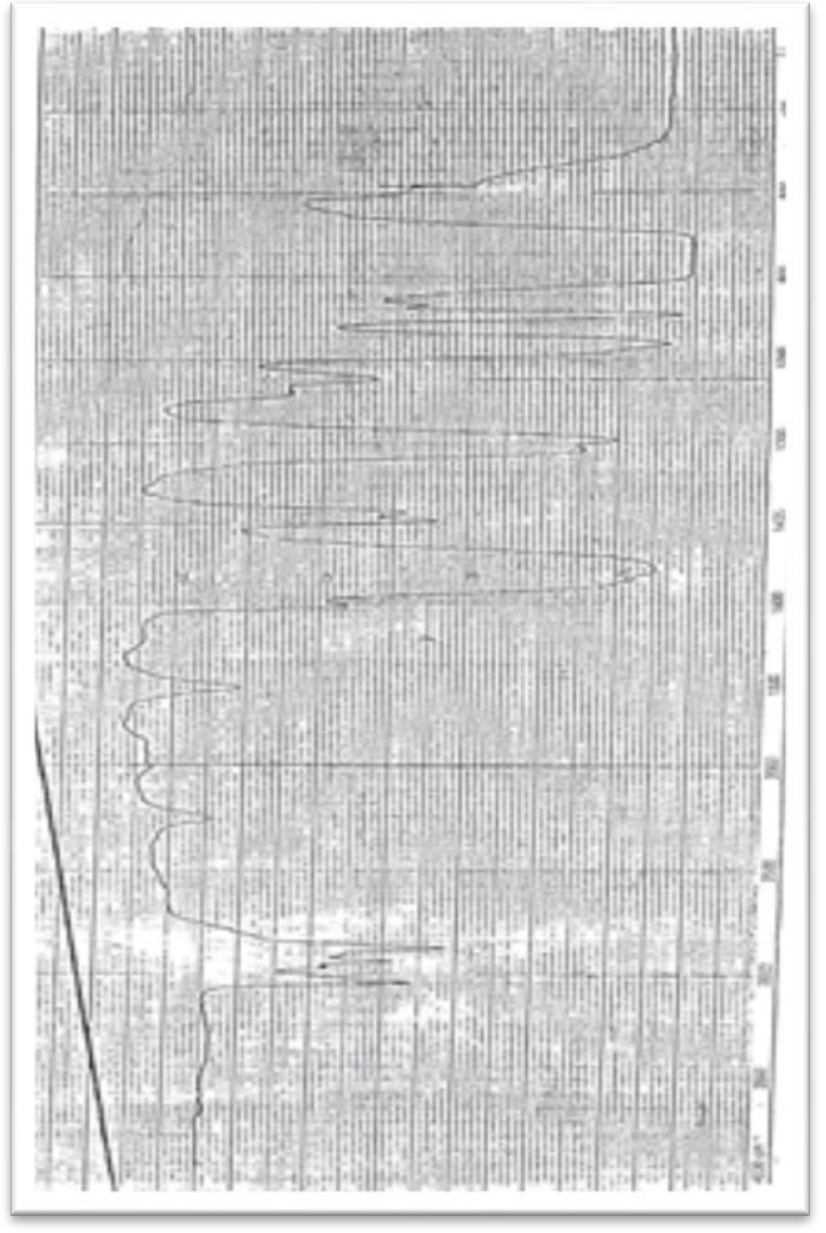

Fig. 8: I.R spectrum of isolated allicin from bulbs of garlic

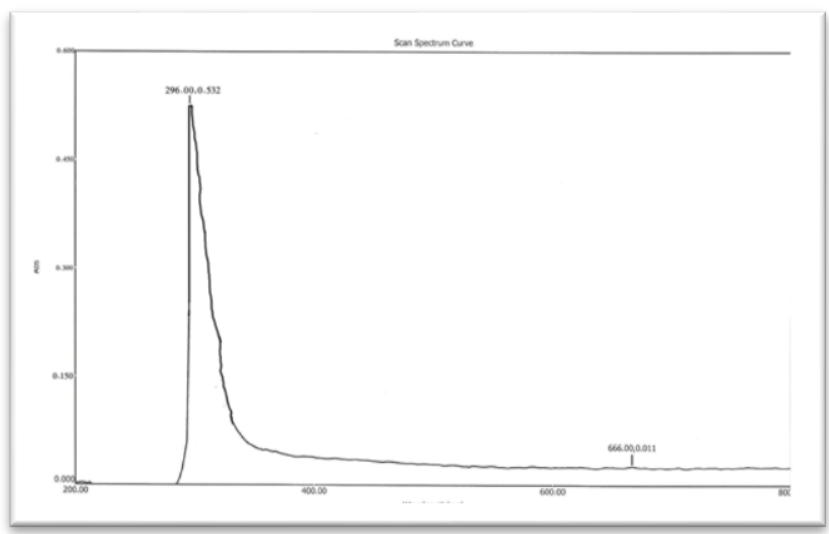

Fig. 10: U.V spectrum of isolated allicin from bulbs of garlic 


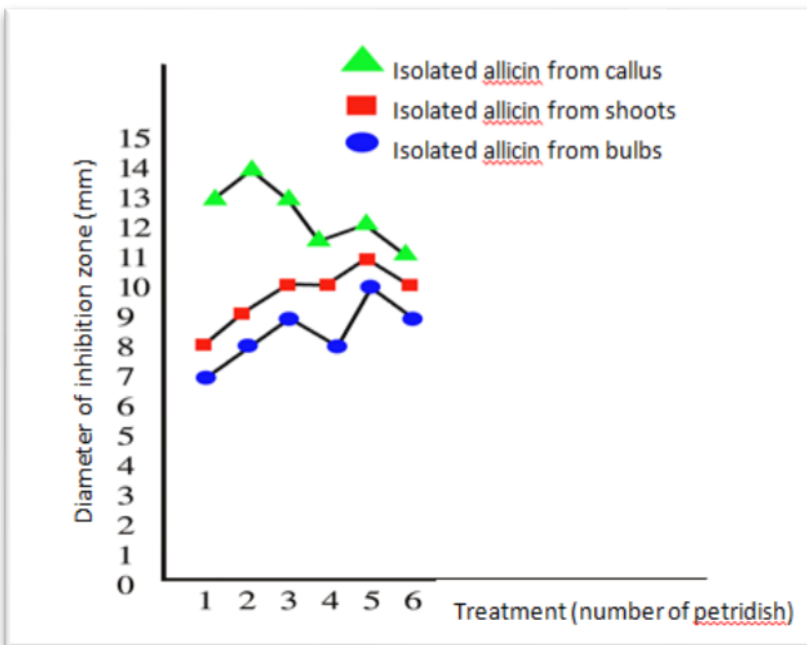

Fig. 11: Sensitivity test of Staphyllococcus aureus toward isolated allicin

\section{References}

Al-Wafi, H. (1998). Study the effect of dry garlic plant powder on lipids and proteins in blood plasma of healthy and sick mens with hypper lipid; M.Sc. Thesis, Sci. Coll. Basrah Univ. pp. 95.

Ayabe, M. and Sumi, S. (2001). Anoval and efficient tissue culture method- " stem-disc dome culture "- for producing virus-free garlic. Plant Cell Reports, 20(6): 503-507.

Barros, S. and Maia, L. (1995). Effect of garlic bulb extract on mycelial growth and spore germination of Curvularia spp. and Alternaria spp. Phytopathologia 21: 168-170.

Bauer, A. ; Kirby, W.; Sherris, J. and Turck, M. (1966). Antibiotic susceptibility testing by standarddised single disc method. Amer.. J. Clin. Pathol., 45:493-496.

Block, E. (1985). The chemistry of garlic \& onions. Amer. Sci., 3: 252-254.

Borukh, I.; Kirbaba, V.; Demkevice, L. and Barabash, O. Yo . (1975). Bactericidal properties of volatile fraction of garlic phytoncides . Prikl Biokhim Microbiol., 11 (3) 478 - 479.

Brace, L. (2002) . Cardiovascular benfits of garlic . J . Cardiovasc Nurs 16 (4): 33 - 49 .

Cavallito, C.; Hays, J. and Allian, B. (1944). The antibacterial principle of Allium sativum L. Isolation, physical properties and antibacterial action . Cited from AL-Wafi, A. M. MSc.

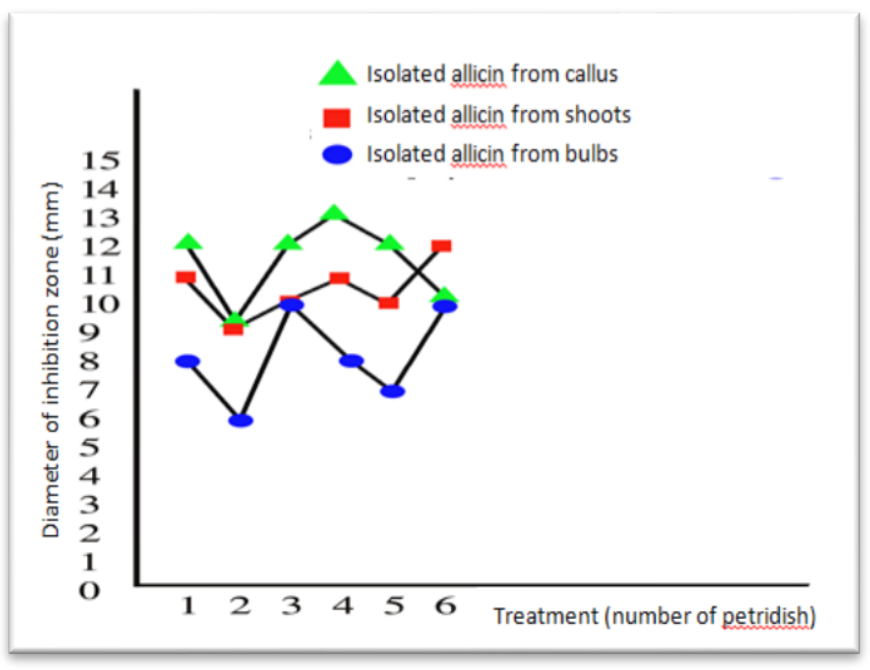

Fig. 11: Sensitivity test of Escherichia coli toward isolated allicin

Thesis, Basra University, Science College. ( 1998).

Chakravarty, H. (1976). Plant Wealth of Iraq , Baghdad, vol. 1: 20-21 .

Chen, H.; Chang, M.; Chang, T. (1985). Antibacterial properties of some spice plants before and after heat treatment [ English translation of Chinese article ] Zhonghua Min Guo Wei Sheng Wu Ji Mian Yi Xue Za Zhi, 18:190-195.

Chen , S. and Huang , J. (1991).Rapid clonal propagation and virus- elimination of garlic. Acta Horticulture Sinica 18: 245-250.

Choi, S.; Paek, K. and Fo, J. (1993). Plantlet production through callus culture in garlic L. J. Korean Soc. Hort. Sci ., 3:16-28.

Harborne, J. (1984). Phytochemical methods :Aguide to Modern Techniques of Plant analysis. 2nd ed. Chapman and Hall, London .

Hassan, N.; El-Halwagi, A.; Gaber, A.; El-Awady, M. and Khalaf, A. (2007). Slow-growth In Vitro conservation of garlic cultivars grow in Egypt: Chemical characterization and molecular evaluation. Global J. of Molecu. Sci. 2(2): 67-75.

Jerzy, J. and Lipo, J. (1990). Fungistatic and Fungicidal activity of Albarep and garlic against phyto pathogenic fungi . Rocz .Nauk Roin . ser. E., (20): 53-59.

Khanna, P. and Rathore, A . (1977) .Diosgenin and solasodine from Solanum nigrum L.Indian J.Exp. Biol., 15: 808 - 809 . 
Khan, N.; Alam, M. and Nath, U. (2004) . In vitro Regeneration of garlic through callus culture, Depart. of Genet. and plant breed., Bangladesh Agricult. Univ., Mymensingh , Bangladesh (2): 189-191 .

Koch , H. (1993). Garlic-Fact or Fiction? The antibiotic substance from garlic. Phytotherapy Res. , 7: $278-280$.

Kudou, R.; Fujime, Y. and Amimoto, K. (1995). Effect of plant growth regulators and sampling positions on organ formation of garlic.Tech. Bull. of the Faculty of Agricult., Kagawa Univ. 47: 15-22.

Lawson , L. (1998). Garlic: a review of its medicinal effects and indicated active compounds. In: Lawson L. ; Bauer, R., eds. Phytomedicines of Europe: Chemistry and Biological activity. Washington, D.: Amer. Chem. Soci.; 177-209.

Masuda, K. ; Hata Keyama, E. ; Ito, A. ; Takahashi, S. and Inoue, M. (1994). Micropropagation of garlic. Bull. Akita pref. Coll. Agr. 20: 43-48 .

Murashige, T. and Skoog, F. (1962). A revised medium for rapid growth and bioassays with tobacco tissue culture. Phsiol. Plant., 15: 473-497.

Nagasawa, A. and Finer, J. (1988). Induction of Morphogenic callus cultures from leaf tissue of garlic, Hortsci. 23(6):1068-1070.

Pai, S. and Platt, M. (1995). Antifungal effects of garlic extract against the Aspergillus species in volved in otomycosis. Lett. Appl. Microbiol., 20: 14-18.

Robledo, P. ; Villalobos, A. and Jofre, G. (2000) .Efficient Plant, regeneration of garlic by root-tip culture. In vitro cellular and Develop. Biol. plant 36: 416-419.

Roksana, R. ; Alam, M. ; Islam, R. and Hossain, M. (2002). In vitro Bulblet formation from Shoot Apex in garlic. Plant Tissue Cult. 12 (1):11-17.

Saleem, Z. (1978). The effect of garlic extraction on Bacillus cereus and some other microbs and on pepsin and trypsin enzymes. Msc. thesis Agric. College-Baghdad Univ. pp. 85.

Shriner, R. ; Fuson, L. ; Curtin, D. and Morrill, T. (1980). The Systemic Identification of Organic Compound. 6th ed. John Willey and Sons, Ins. New York, U.S.A .

Staba, E. ; Lash, L. and Staba, J. (2001). A commentary on the effects of garlic extraction and formation on product composition. J. Nutrition., 131(3): 1118-1119.

Takagi, H. (1990). Garlic, Onion and Allied Crops , Boca Rataon, USA, 3: 109-146.
Tynecka, A. and Gos, Z. (1973). The inhibitory action of garlic. on growth and respiration of some microorganisms. Acta. Microbiol. pol. ser. 5:5162.

Zenk, M. (1978). The impact of plant tissue culture on industry in; Thorpe.T. (cd.). Frontiers of plant tissue culture. 1978. proc. $4^{\text {th }}$ Int'l congress of plant tissue and cell culture Calgary. Canada pp. $1-13$. 